9-1997

\title{
First Lessons: Charter Schools as Learning Communities
}

Priscilla Wohlstetter

Noelle Griffin

Follow this and additional works at: https://repository.upenn.edu/cpre_policybriefs

Part of the Curriculum and Social Inquiry Commons, Educational Leadership Commons, Education Policy Commons, and the Teacher Education and Professional Development Commons

\section{Recommended Citation}

Wohlstetter, Priscilla and Griffin, Noelle. (1997). First Lessons: Charter Schools as Learning Communities. CPRE Policy Briefs.

Retrieved from https://repository.upenn.edu/cpre_policybriefs/9

View on the CPRE website.

This paper is posted at ScholarlyCommons. https://repository.upenn.edu/cpre_policybriefs/9

For more information, please contact repository@pobox.upenn.edu. 


\title{
First Lessons: Charter Schools as Learning Communities
}

\author{
Abstract \\ Twenty-eight states, over the past six years, have authorized the creation of charter schools as an \\ alternative form of public education. Charter schools are seen as opportunities to create highperforming \\ learning communities, with improved student performance and other positive results as the goals of \\ these new institutions. \\ The creation of high-performing learning communities is central to the success of charter schools, but we \\ need to know if these schools, as currently constituted under their enabling legislation, are capable of \\ creating such learning communities. We want to know what elements help to build or to obstruct these \\ learning communities. To answer these questions, Consortium for Policy Research in Education (CPRE) \\ researchers became acquainted with the founders, teachers and administrators in 17 charter schools in \\ Boston, Los Angeles and Minneapolis/St. Paul. \\ Charter schools provide, within the public education system, a new governance structure that is freed \\ from most district and state regulations. Charter schools are intended to increase consumer choice \\ within the public education system. And, most importantly, charter schools are meant to encourage \\ innovation in teaching and learning practices in order to improve student performance. A 1995 survey of \\ charter school founders, conducted by the Education Commission of the States, reported that "better \\ teaching and learning for all kids," "running a school according to certain principles and/or philosophy," \\ and "innovation" were the top three reasons for starting a charter school.

\section{Disciplines} \\ Curriculum and Social Inquiry | Educational Leadership | Education Policy | Teacher Education and \\ Professional Development

\section{Comments} \\ View on the CPRE website.
}




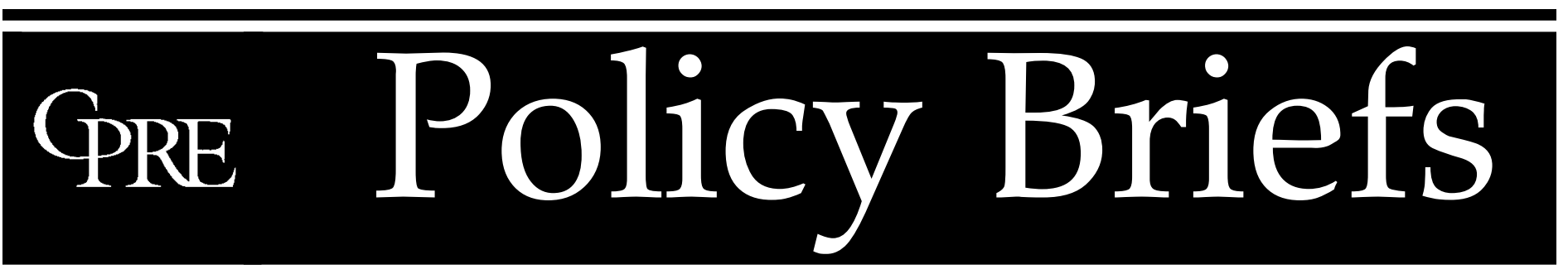

\title{
Reporting on issues in education reform
}

\author{
Graduate School of Education \\ - $\quad$ University of Pennsylvania \\ - \\ RB-22-September 1997
}

\section{First Lessons: Charter Schools as Learning Communities}

\section{by Priscilla Wohlstetter and Noelle C. Griffin}

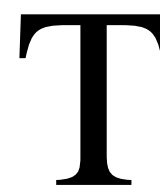

wenty-eight states, over the past six years, have authorized the creation of charter schools as an alternative form of public education. Charter schools are seen as opportunities to create highperforming learning communities, with improved student performance and other positive results as the goals of these new institutions.

The creation of high-performing learning communities is central to the success of charter schools, but we need to know if these schools, as currently constituted under their enabling legislation, are capable of creating such learning communities. We want to know what elements help to build or to obstruct these learning communities. To answer these questions, Consortium for Policy Research in Education (CPRE) researchers became acquainted with the founders, teachers and administrators in 17 charter schools in Boston, Los Angeles and Minneapolis/St. Paul.

Charter schools provide, within the public education system, a new governance structure that is freed from most district and state regulations. Charter schools are intended to increase consumer choice within the public education system. And, most importantly, charter schools are meant to encourage innovation in teaching and learning practices in order to improve student performance. A 1995 survey of charter school founders, conducted by the Education Commission of the States, reported that "better teaching and learning for all kids," "running a school according to certain principles and/or philosophy," and "innovation" were the top three reasons for starting a charter school. ${ }^{1}$
Charter schools differ from regular schools in important ways, most notably in their autonomy from state and district regulations and requirements. Charter schools also differ from one another, in that each charter school is governed by its own charter spelling out its particular structure and programs.

The ability of charter schools to get their programs up and running, and to sustain these programs has varied from school to school. The charter schools' impact on student achievement presumably varies as well, but is unclear due to insufficient or inadequate evaluations. Still, charter schools have been in existence long enough to look for lessons from their experiences.

Unlike many recent studies of charter schools that focus on the fiscal, legal and bureaucratic issues they face, this issue of CPRE Policy Briefs examines the goals and implementation issues specifically related to teaching and learning. This policy brief summarizes, "Creating and Sustaining Learning Communities: Early Lessons from Charter Schools," a study by Priscilla Wohlstetter and Noelle C. Griffin which explored how learning communities were created and sustained in 17 charter schools in one city in each of three states: in Los Angeles, California; Boston, Massachusetts; and Minneapolis/St. Paul, Minnesota.

This study was based on the assumption that strong learning communities enhance student performance. ${ }^{2} \mathrm{CPRE}$ researchers conducted focus group discussions with charter school founders, administrators and teachers, and reviewed 
the charter school proposals, demographic and assessment data and other documents for each of the 17 charter schools. This study examined:

- How school missions were developed and translated into classroom practice;

- How charter schools learned from what they were doing; and

- What factors were likely to produce high-quality teaching and learning in charter schools.

The CPRE researchers identified four building blocks used by the charter schools, some more successfully than others, to create and sustain learning communities: the school's mission; the school's instructional program; the school's accountability system; and the school's leadership. The information gathered during this study suggests that certain enabling conditions may contribute to a charter school's effectiveness in creating and sustaining its learning community.

\section{Charter School Building Block: The School Mission}

The school mission is the foundation from which everything else in a school is derived. When the mission is clear and specific, a school is better able to translate its mission into practice. In many of the charter schools studied, the mission grew out of strong, passionate feelings about schools and education, and as the schools evolved, the mission helped to sustain the interest, participation and commitment of teachers, parents and students. The mission statement is sometimes used to communicate fundamental beliefs and expectations to job candidates and prospective students.

The prior experience of those involved in drafting the school's mission statement and charter appears to affect the ease with which they made the transition from vision to operational school. Smoother transitions from mission to practice were made by those who had prior instructional and managerial experience in schools. Charter schools converted from pre-existing schools and those connected with national reform efforts had easier times getting started because of their prior experience. Inexperienced founders, regardless of their commitment, had more difficulty proceeding once their charters were approved because of their lack of know-how.

Schools in which staffs solicited input or feedback about their schools' mission statements from key stakeholders-teachers, parents and students had fewer conflicts later with those stakeholders. The California charter law mandates teacher involvement; the
California charter schools in the study generally included more stakeholders in developing their missions.

The 17 charter schools examined by CPRE researchers had remarkably similar themes in their mission statements despite differences in how the statements were developed, the makeup of their student populations, or the levels of schooling provided. These common themes included: preparing students for a changing society in the $21^{\text {st }}$ century; technology preparedness; and consideration of the "whole student" in terms of his or her academic, emotional and social development.

Many of the charter schools in the sample adopted mission statements which were too broad and lacked specificity. Some of these schools faced problems later when they attempted to translate their missions into specific curricular or assessment practices, or to provide staff members with direction about teaching and learning.

\section{Charter School Building Block: The Instructional Program}

A high-quality instructional program
clearly describes the school's curricula
and pedagogy, and details how teach-
ers lead all students to perform at high
levels. Few representatives of the char-

\section{About CPRE Briefs}

CPRE briefs are published occasionally by the Consortium for Policy Research in Education. The study reported in this issue was supported by a grant from the Danforth Foundation. Additional support was provided by the Consortium for Policy Research in Education (CPRE), Grant No. OERI-R308A60003 from the National Institute on Educational Governance, Finance, Policymaking and Management, Office of Educational Research and Improvement, U.S. Department of Education. The views expressed in this publication are those of its authors and are not necessarily shared by the Danforth Foundation, the U. S. Department of Education, the Consortium, or its institutional members. 
ter schools included in this study, however, described well-articulated and integrated instructional programs or consistent, content-based professional development systems.

The instructional program should follow directly from the school mission. Vague school missions made it more difficult for many of these schools to develop coherent instructional programs. Short time frames for getting instructional programs operational exacerbated the problem, particularly in charter schools that were not conversions of pre-existing district schools.

Many charter school participants expressed a strong desire to create their own instructional programs. The "make versus buy" dilemma was common to many of the schools studied, but because of time constraints, most used curricula developed by educators and reformers outside their schools, or combined curricular pieces from different sources. The majority of schools purchased parts or all of their instructional programs rather than creating them, and they faced challenges in integrating their unique school missions and ideas about education with the offthe-shelf materials. For example, one middle school's mission emphasized an integrated, holistic curriculum with real-world applicability but, early on when they felt the pressure to put a program in place, adopted the "University of Chicago Math" and "Montana Math" programs despite the fact that the curricula contradicted the school's philosophy of not teaching math as a separate subject. Schools that devoted more preparation and effort to finding instructional programs more consistent with their school missions were better able to integrate their mission and instructional program.
About one-third of the charter school staffs created their instructional programs from scratch, often doing so as they went along. This approach was most characteristic of the charter schools in Minnesota where the schools served at-risk or dropout student populations, and tended to be smaller.

The charter schools in this study emphasized some similar instructional approaches. These common characteristics included:

- Low student-to-staff ratios and small class sizes (Class size ranged between ten and twenty students in the three charter schools with more than 1,000 students; in schools of fewer than 100 students, class sizes often included ten or fewer students.)

- Personalized learning, such as developing individualized learning plans for students

- Interdisciplinary approaches that use "real-world" projects

- A focus on integrating the school with the community (Examples include: school-business partnerships, community service requirements for graduation, involvement of parents and other community members as tutors.)

Curriculum decisions sometimes involved broad groups of stakeholders in committees, task forces, grade-level teams or subject-area teams. All the California charter schools in the sample were conversions of school-based management district schools, which may explain why they created formal decision-making structures. Several other charter schools in the sample had no decision-making structures in place when they opened their doors.
The professional culture for educators across the charter schools was an eclectic mix, often characterized by high levels of professionalization and commitment but, at the same time, many instances where teachers seemed to ignore existing professional knowledge and expertise.

Teachers in the charter schools generally expressed a strong sense of collective responsibility for instruction at their schools, regardless of faculty size. They recognized the importance of continuous improvement, open and collective problem-solving, and reflection about classroom practice. Although informal collaboration among teachers on matters of teaching and learning appeared to be common, there were few formal structures for collaboration. Dialogue among teachers was not usually systematic, rather, it depended on individuals' taking the initiative to visit with colleagues.

Underlying certain curriculum decisions made in the charter schools there was often an assumption of expertise: teachers have the expertise; all they need is a good curriculum. At one middle school, for example, after math manipulatives and math games were selected, it was just assumed that teachers would know what was expected without any organized or ongoing training. One elementary school purchased Hirsch's core classical curriculum, but rejected the recommended training.

Few focus group participants reported any consistent system of professional development, either to provide training or ongoing planning time so teachers could gain the knowledge and skills needed to implement the curriculum effectively. When time was set aside for professional development, it tended to be used more for planning and school culture-building 
than for helping teachers to master new skills related to curriculum and instruction.

Some of the charter schools that converted from existing public schools were exceptions to this lack of systemic attention paid to professional development. Focus group participants from conversion schools were more likely than those from start-up schools to say that their schools attempted to use professional knowledge in making curricular decisions. One conversion school created a curriculum committee to investigate curricular changes; another conversion school hired a "standards consultant" to inform teachers about national and district standards. Another former schoolbased management school required staff members to attend professional development retreats on specific curricular changes each semester, then monitored the extent to which the particular curriculum change was implemented in the classrooms.

\section{Charter School Building Block: The Accountability System}

One of the basic premises of charter schools is that they should be allowed greater autonomy in exchange for greater accountability for results. ${ }^{3}$ A charter school accountability system requires performance standards for judging whether or not the school meets its goals; assessment strategies for evaluating student performance; and consequences - either rewards or sanctions-based on the school's success or failure in meeting its goals.

The accountability requirements of the agencies sponsoring the charter schools in the three states studied, however, were relatively weak. The states required assessment information but rarely required clear performance standards or established consequences. Sponsoring agencies have focused to date more on standards of fiscal management and, to a lesser degree, on general probity and scandal avoidance than on reasonable progress toward schools' meeting their own student goals. ${ }^{4}$

Massachusetts is considered one of the states with the most stringent accountability requirements. Massachusetts charter schools are subject to one-day evaluation site visits, and the success of the academic program is one of three evaluation areas for charter schools. Massachusetts charters are subject to renewal every five years, but it is not evident what level of school performance is satisfactory for renewal, or whether the state can close a school for non-performance.

Charter schools in the three states studied-California, Massachusetts and Minnesota - are generally expected to establish their own performance goals and formal accountability systems, and to seek their approval from the sponsoring agencies. Out of necessity,

\section{Centralized vs. Decentralized Management: A Tale of Two Schools}

The experience of many charter schools in this study suggests that finding a balance between centralized and decentralized management is a critical issue. Focus group participants described this as an evolving process during the first few years, and noted it was easier to achieve a satisfactory balance early in a school's life before structures become too entrenched or unwieldy.

When an elementary school first converted to charter school status, school leaders attempted to involve all teachers and staff members, and parents to a certain extent, in every important decision. After three years of total inclusiveness, the participants felt that this process was slowing down their ability to make and implement decisions. They decided that everyone cannot manage every aspect of the school, and agreed to institute some top-down structures so the school could function more effectively.

When a new secondary charter school first opened, the staff attempted to make all decisions by full consensus but found that, in effect, they were not making any decisions at all. In the second year, the faculty shifted in the direction of wanting a school leader and more centralized decision-making structures. 
many of the charter schools bought standardized testing materials, and focus group participants expressed concern that the assessments were not tailored to their schools' instructional programs. What has emerged is a continuing dispute over standards for student performance: should the performance of charter schools be judged by the relative improvement of their students based on the school's unique mission and goals, or by state performance standards like other public schools? Focus group participants also noted the difficulty in evaluating outcomes related to non-academic goals, such as students' social and emotional development.

The strongest feeling of accountability reported by the focus group participants was to the local school community, particularly to parents and students. None of the schools studied had strong internal accountability systems in place, but many participants said they were working on developing a formal accountability system. In the meantime, these schools used informal progress reports, annual satisfaction surveys and student enrollment as key indicators to measure school effectiveness.

Just as negative consequences of school failure are absent or unclear, so are positive rewards for good performance by a charter school. With one exception, neither charter schools nor their teachers received significant monetary rewards based on performance. More common were "soft" extrinsic rewards, such as faculty appreciation luncheons, recognition in school newsletters, and the like. The rewards of working in a charter school were mentioned more frequently by charter school teachers and administrators; these rewards included professional collaboration, greater control

\section{Growth of Charter Schools}

- Since 1991, when Minnesota passed the first charter school law, 28 states and the District of Columbia have passed some form of charter school legislation.

- There are nearly 500 charter schools in operation in the United States, the majority of which are elementary schools.

- Federal funding for charter schools increased from \$6 million in 1995 to \$18 million in 1996 to \$51 million in 1997.

- Sixty-three percent of students who attend charter schools nationally are members of minority groups.

over the school, and other positive working conditions.

\section{Charter School Building Block: School Leadership}

School leadership is an important factor in fostering effective teaching and learning. School leaders play multiple roles and often have to balance between responsibilities related to managerial and instructional leadership.

Managerial and instructional responsibilities were divided in some of the charter schools in this study; in other schools one person or group was responsible for both areas. Schools with the greatest autonomy from their districts were more consumed by managerial decisions and day-to-day operational issues, leaving less time to attend to issues of teaching and learning.

Focus group participants reported certain characteristics common among school leaders. Charter school leaders often perceived themselves as having an "outlaw mentality," coming from outside the public school system or having a willingness to fight the status quo in public education. Many charter school leaders shared a sense of entrepreneurship in that they forged linkages with resources outside the district, including professional networks, community partnerships and new service providers. Representatives of the charter schools believed that leadership arose from collaboration between administrators and teachers, from teams of people working toward a common goal.

Individuals involved in the initial design and development of charter schools generally rejected hierarchical structures typical of the public school system and valued a more even distribution of power within the school community. Designing the organizational structure at many of the charter schools studied was an evolutionary process in which participants struggled to find a balance between centralized and decentralized management structures. Desire for total staff inclusiveness in decision-making vied with concern about greater efficiency and more timely action. Very few school leaders had a strong professional understanding of how to balance the process. Many charter school leaders had only teaching and no management experience. Even administrators with 
previous managerial experience found that running a charter school presented new challenges and demands.

\section{Enabling Conditions}

The charter schools examined in this study had varying degrees of success in putting into place their school missions, instructional programs, accountability systems, and effective leadership. The CPRE researchers conducting this study identified three enabling conditions that help to explain this variability: school power and autonomy; support networks and organizations; and supportive parents. These enabling conditions also help to explain how charter schools might become more successful in creating and sustaining learning communities, and what types of outside support might be made available to make charter schools more effective.

\section{Charter School Enabling Condition: School Power and Autonomy}

The charter schools with the greatest control over their budgets, personnel, school governance and curriculum were generally better able to create and sustain their learning communities. They used school funds in new ways tailored to specific school needs, including facilities, curricular materials, professional development, or monetary incentives for teachers. Charter schools with the greatest control experimented with decision-making structures and changes in school-year and weekly schedules. They were better able to avail themselves of community opportunities and resources, and to implement innovations in teaching and learning. Because they did not have to obtain district approval of their decisions, these schools seemed able to adopt new curricular programs or respond to problems more quickly.

It might be expected, therefore, that the most successful charter school laws would be those that grant greater autonomy to charter schools. A great deal of autonomy, however, is not necessarily sufficient in and of itself. A strong organizational capacity in support of teaching and learning is needed to make good use of increased autonomy. Schools having weak organizational structures appeared to have more difficulty in capitalizing on their autonomy. Charter schools require the authority to implement curricular and organizational changes, but they also need leaders with the professional background and capacity to harness this power.

\section{State Teaching and Learning Goals for Charter Schools}

\section{California}

- Improve pupil learning

- Increase learning opportunities for all pupils, with special emphasis on expanded learning opportunities for pupils identified as academically low-achieving

- Encourage use of different and innovative teaching methods

- Create new professional development opportunities

\section{Massachusetts}

- Stimulate the development of innovative programs in education

- Provide opportunities for innovative learning and assessment

- Provide teachers with a way to establish schools having alternative, innovative methods of instruction, school structure and management

\section{Minnesota}

- Improve pupil learning

- Increase learning opportunities for pupils

- Encourage use of different and innovative teaching methods

- Create new professional opportunities for teachers, including the opportunity to be responsible for the school learning program 


\section{Charter School Enabling Condition: Support Networks and Organizations}

Charter schools received advice and support primarily from national education reform networks and from organizations created specifically to assist charter schools. The national reform networks generally provided help in the areas of curriculum and instruction, often through professional development workshops. The workshops were not usually tailored to charter schools, but served both charter and non-charter schools belonging to the network.

Charter school advocates often operate charter school support organizations that provide a variety of services: workshops; site visits; individual school assistance and assessments; opportunities for charter school staff members to share problems and practices; outreach to the corporate and foundation community; legal research; and policy education about charter school laws and implementation issues. All three states studied had nonprofit resource centers providing such technical assistance to prospective and operating charter schools.

Neither the federal nor state governments in California, Massachusetts and Minnesota, the three states included in this study, provided technical assistance to charter schools, although federal and state policymakers in all three states were supportive of charter schools. States that enacted charter school laws usually established charter school units within their state departments of education. The main purpose of these units was not providing technical assistance, but administer- ing the law, including oversight of the application process, and evaluating implementation of the law and accountability systems. In contrast, Great Britain started its version of charter schools and established an organization for the "grant-maintained" schools at the same time in 1989. This organization assisted schools as they moved to charter status, and provided technical assistance to the schools after they opened. ${ }^{5}$

\section{Charter School Enabling Condition: Supportive Parents}

A base of supportive parents facilitates the creation of a charter school and nurtures its ongoing development. $\mathrm{Pa}-$ rental interest can be a driving force in inspiring the passion and creating the commitment to start a new school. After all, a group of interested consumers is necessary for a charter school to have students. In many of the charter schools in this study, parents provided a great deal of encouragement and assistance in starting the school. In a few schools, however, parental interest quickly became perceived as parental meddling when parents protested curricular plans or took an active role influencing other school decisions.

Overall, ongoing parental support and involvement was seen by the focus group participants as critical to the success of the charter schools. Parents volunteered for tutoring programs and school activities; participated in training sessions, discussion groups and decision-making structures; donated time to improve facilities; and provided financial support through booster clubs. The schools without this kind of parental support encountered noticeable difficulties.

\section{Conclusion}

It is hard work to design and operate a school focused on teaching and learning. Charter school leaders must learn to balance the demands of curricular issues with those associated with financial, organizational and public relations issues. ${ }^{6}$ Our focus group discussions with charter school founders, administrators and teachers suggested that the following factors were most likely to support the development of high-quality teaching and learning:

\section{School Mission}

- A clear and specific school mission

- Involvement of key stakeholders in developing the school mission

\section{Instructional Program}

- A well-articulated and integrated instructional program that supports the school mission

- A sense of collective responsibility among staff members for teaching and learning in the school

- A consistent, content-based professional development program that helps teachers implement the instructional program

- Development of formal structures for staff collaboration and planning

- Orientation toward constant evolution and adaption to changing demands and new information; continual reexamination of practices and methods; ability to make informed changes along the way

Note: At the time this research was conducted, the finding that the federal and state governments in California, Massachusetts and Minnesota did not provide technical assistance to charter schools was accurate. However, since the time this policy brief was written, the situation has changedall three states do now provide technical assistance or oversight to charter schools. 


\section{Accountability System}

- Clear performance standards which can be used to determine if the school is meeting its goals

- Assessments of student performance linked to the school's educational goals

- Rewards for schools and teachers based on performance

- Clear consequences for failure of school to perform

\section{School Leadership}

- Prior instructional and managerial experience of school founders and leaders

- Ability to cultivate and manage effectively alternative resources, such as national reform networks, management and fiscal experts, the business and social service communities, colleges and universities, consultants in academic standards and assessment, and administrators from the state department of education

\section{School Power and Autonomy}

- A high degree of autonomy and control over the school budget, personnel, school governance and curriculum

- A decision-making structure that balances inclusiveness of staff, parents and others with the need for school leaders to make some decisions to maintain efficiency and timeliness

\section{Support Networks and Organizations}

- Availability of technical assistance and support in goal-setting, accountability issues, legal requirements, business matters, and curricular and instructional issues

\section{Supportive Parents}

- High level of parental support

Some of these factors contributing to high-quality learning communities are within the power of the charter school leaders and staff members. The outlook for charter schools can be further improved by better charter school laws that demand more specificity from applicants and sponsoring agencies, and through the support and assistance of many outside experts and groups. Only when all of these factors are present will charter schools really be able to focus on teaching and learning, and to fulfill their vision of high student achievement

\section{Endnotes}

1. Education Commission of the States. (1995, August). Charter Schools: What are they up to? Denver: Author.

2. Louis, K.S., Marks, H.M., \& Kruse, S. (1996). Teachers' professional community in restructuring schools. American Educational Research Journal, 33(4), 757-798; Odden, A.R., \& Wohlstetter, P. (1995). How schools make school-based management work. Educational Leadership, 52(5), 32-36; Wohlstetter, P., Van Kirk, A.N., Robertson, P.J., \& Mohrman, S.A. In press. Organizing for successful school-based management. Alexandria, VA: Association for Supervision and Curriculum Development.
3. Wohlstetter, P., Wenning, R., \& Briggs, K.L. (1995). Charter schools in the United States: The question of autonomy. Educational Policy, 9(4), 331-358.

4. Finn, C.E., Manno, B.V., \& Bierlein, L. (1996). Charter schools in action: What have we learned? Indianapolis, IN: Hudson Institute Educational Excellence Network.

5. Wohlstetter, P., \& Anderson, L. (1994). What can U.S. charter schools learn from England's grant-maintained schools? Phi Delta Kappan, 75, 486491.

6. Nathan, J. (1996). Charter Schools: Creating hope and opportunity for American education. San Francisco: Jossey-Bass.

\section{Other References}

Buechler, M. (1996, January). Charter schools: Legislation and results after four years (Policy Report No. PRB13). Bloomington: Indiana Policy Center.

Wohlstetter, P., \& Griffin, N. (1997). Creating and sustaining learning communities: Lessons from charter schools. Paper presented at the annual meeting of the American Educational Research Association, Chicago.

\section{About the Authors}

Priscilla Wohlstetter is a senior research fellow with the Consortium for Policy Research in Education (CPRE) and associate professor at the University of Southern California School of Education, where she directs the Center on Educational Governance. She is currently directing a national study of how charter schools create successful learning communities. She has 
served as principal investigator of several large studies examining the relationship between decentralized management and school performance, and is a recognized expert for her work on school-based management.

Noelle C. Griffin, a doctoral candidate at the University of Southern California, works closely with Priscilla Wohlstetter in researching charter schools and site-based management. She is a research associate of a Danforth Foundation funded project that is examining accountability issues and the creation of learning communities in charter schools, and co-author with Priscilla Wohlstetter of the paper, "Creating and Sustaining Learning Communities: Early Lessons from Charter Schools," presented at the American Educational Research Association in 1997.

\section{Acknowledgments}

The authors would like to thank the following for their assistance with data collection and their useful comments on early drafts of the paper, "Creating and Sustaining Learning Communities: Early Lessons from Charter Schools": Charles Abelmann and Richard Elmore of Harvard University; Janice Ballou of the Eagleton Institute of Politics, Rutgers University; and Allan Odden of the University of Wisconsin-Madison.

\section{More on the Subject}

Copies of Priscilla Wohlstetter and Noelle Griffin's full-length report, "Creating and Sustaining Learning Communities: Early Lessons from Charter Schools" will be published as a CPRE Occasional Paper in Fall 1997 ; the cost is $\$ 5.00$. To obtain copies, write to CPRE at the address provided in the box to the right.

\section{Recent CPRE Publications}

Persistence and Change: Standards-based Reform in Nine States Diane Massell, Michael Kirst, and Margaret Hoppe (No. RR-037, April 1997) $\$ 10$

This report explores the persistence and transformation of standards-based instructional guidance strategies, and the issues and challenges that states and districts have confronted as they tried to implement these policies. It is based on extensive interviews conducted during 1994-95 in 9 states-California, Connecticut, Florida, Georgia, Kentucky, Minnesota, New Jersey, South Carolina and Texas and 25 districts in those states. Please note: $\boldsymbol{A}$ Policy Brief based upon this report is available from CPRE free of charge. To obtain, please write to $C P R E$, referencing $R B-21$, at the address below.

Public Policy and School Reform: A Research Summary (No. RR-036, March 1996) \$5

Standards-based reforms and increased professional development focused on content have helped to improve schooling and boost student achievement. But policymaking still suffers from unrealistic expectations, too much emphasis on structural change, and not enough attention to factors directly linked to student achievement. This summary attempts to highlight promising strategies and policy initiatives while helping policymakers avoid past pitfalls. The report addresses topics including standards-based reform, restructuring, policy and classroom practice, capacity, school finance, and educational productivity.

Teacher Professional Development Profiles, a product of CPRE's 50-state study on professional development, are available through the Consortium for Policy Research in Education. Designed to provide an information base for state policymakers interested in improving teacher learning opportunities, these profiles are useful for stimulating discussion about professional development. Please call 215-573-0700, x0 for pricing information.

\section{Ordering Information}

To obtain copies of CPRE Research Reports and Occasional Papers, write: CPRE Publications, Graduate School of Education, University of Pennsylvania, 3440 Market Street, Suite 560, Philadelphia, PA 19104-3325. All orders must be prepaid with U.S. funds drawn from U.S. banks; make checks payable to Trustees of the University of Pennsylvania. Please note: sales tax is not applicable.

To obtain copies of CPRE Policy Briefs, write to the address above or email us at cpre@gse.upenn.edu. There is no charge for single copies. 


\title{
Upcoming CPRE Publications
}

\section{CPRE Policy Briefs}

\author{
A Comparative Analysis of State Professional Development Policies and Programs \\ by Thomas B. Corcoran
}

Professional development policies in many of the 50 states are fragmented, unfocused and not cost-effective. However, promising changes are underway in some states. To improve the effectiveness of these investments, state policymakers should first know much money is spent on professional development and how state policies affect local professional development decisions. This report describes actions taken by other states to improve teacher learning opportunities-from adopting state professional development plans, mandating local plans, providing state grants or directly underwriting programs, to establishing incentives for advanced certification.

\section{CPRE Occasional Papers}

\section{Creating and Sustaining Learning Communities: Early Lessons from Charter Schools by Priscilla Wohlstetter and Noelle C. Griffin}

High-quality teaching and learning have always been key goals of those who design and support charter schools, but little research to date has addressed how charter schools create and sustain learning communities. Based on a sample of 17 charter schools in three states, the authors look at how charter schools developed and translated their missions into classroom practice, how charter schools learned from what they were doing, and what factors were most likely to produce high-quality teaching and learning in charter schools.

\section{California Curriculum Policy in the 1990s: "We Don't Have to Be in Front to Lead" by Lisa Carlos and Michael Kirst}

Throughout the 1980s California was considered a leader in break-the-mold education reforms, influencing other states and federal policy. Declining state revenues, preoccupation with budget battles and leadership changes, however, interrupted and redirected some of these reforms. This case study traces the evolution of California's curriculum reforms, especially those influencing mathematics and science instruction, and examines the reforms in the shifting political and policy context. The role of the California Department of Education is central to this study.

\section{CPRE Research Reports}

\section{Rethinking the Allocation of Teaching Resources: Some Lessons from High Performing Schools by Karen Hawley Miles and Linda Darling-Hammond}

Very little of the debate surrounding the level and allocation of resources to public schools addresses how schools might organize teaching resources more effectively at the school level. This paper describes case studies of five high-performing schools that have organized professional resources in innovative ways. These concrete alternatives to traditional organization of teachers are based on the schools' instructional goals and objectives. Five principles of resource allocation shared by these five very different schools are outlined in this paper.

\section{The Effect of Curriculum-Based External Exit Exam Systems on Student Achievement by John H. Bishop}

A system of curriculum-based external exams has real consequences for students, and achievement is not defined relative to other students in the class or school. This study shows how these systems are organized by discipline, keyed to the content of specific course sequences, signal multiple levels of achievement in a subject, and cover all secondary schools. Colleges and employers give greater weight to academic achievement in curriculum-based external exit exam systems. Countries and Canadian provinces with such systems outperform other countries and provinces at a comparable level of development. 


\section{About CPRE}

The Consortium for Policy Research in Education (CPRE) unites five of the nation's leading research institutions in an exciting venture to improve student learning through research on education policy, governance, and finance. Members of CPRE are the University of Pennsylvania; Harvard University; Stanford University; the University of Michigan; and the University of Wisconsin-Madison.

CPRE conducts research on issues such as:

- education reform

- student and teacher standards

- state and local policymaking

- education governance

- school finance

- teacher compensation

- student incentives

To learn more about CPRE or CPRE publications, please call 215/573-0700, then press 0 for assistance. CPRE's home page can be found at:

http://www.upenn.edu/gse/cpre/

\section{Nondiscrimination Statement}

The University of Pennsylvania values diversity and seeks talented students, faculty and staff from diverse backgrounds. The University of Pennsylvania does not discriminate on the basis of race, sex, sexual orientation, religion, color, national or ethnic origin, age, disability, or status as a Vietnam Era Veteran or disabled veteran in the administration of educational policies, programs or activities; admissions policies, scholarships or loan awards; athletic, or University administered programs or employment. Questions or complaints regarding this policy should be directed to Executive Director, Office of Affirmative Action, 1133 Blockley Hall, Philadelphia, PA 19104-6021 or (215) 8986993 (Voice) or (215) 898-7803 (TDD).

\section{CPRE Management}

\section{Susan H. Fuhrman}

Chair, Management Committee

Graduate School of Education

University of Pennsylvania

3700 Walnut Street

Philadelphia, PA 19104-6216

\section{Thomas Corcoran}

Margaret Goertz

Co-Directors

Graduate School of Education

University of Pennsylvania

3440 Market Street, Suite 560

Philadelphia, PA 19104-3325

\author{
Allan R. Odden \\ Co-Director \\ Wisconsin Center for Education Research \\ University of Wisconsin-Madison \\ 1025 West Johnson Street \\ Madison, WI 53706-1796 \\ David K. Cohen \\ 4109C School of Education \\ University of Michigan \\ Ann Arbor, MI 48109-1259 \\ Michael Kirst \\ School of Education \\ Stanford University \\ Stanford, CA 94305
}

\section{Richard F. Elmore}

\section{Co-Director}

Graduate School of Education

Harvard University

Monroe C. Gutman Library

Appian Way

Cambridge, MA 02138-3704 